\title{
SNACK BAR MADE FROM SORGHUM AND BEANS WITH ADDITION OF RED PALM OIL AS SUPPLEMENTARY FOOD FOR PREGNANT WOMEN WITH CHRONIC ENERGY DEFICIENCY
}

\author{
Aisyah Nurhusna ${ }^{1}$, Sri Anna Marliyati ${ }^{*}$, Eny Palupi ${ }^{1}$ \\ ${ }^{1}$ Community Nutrition Department, Human Ecology Faculty, IPB University, Indonesia \\ *E-mail: anna_marliyati@yahoo.com
}

\begin{abstract}
The prevalence of chronic energy deficiency in pregnant women was in poor conditions since 2016 to 2018 . One of the solution to overcome chronic energy deficiency in pregnant women is by providing supplementary food as snack, such as snack bar. Snack bar was made from sorghum and beans (red bean and black soybean) which are local food source of energy and protein. The objective of this study was to develop and analyze sorghum and beans-based snack bar with addition of red palm oil (RPO) as supplementary food for pregnant women with chronic energy deficiency. This study used complete randomized design with the ratio of sorghum flakes and beans chunks with the addition of RPO as treatment in three replications. Determination of selected formula were based on sensory analysis and protein content of product. The selected formula was F4 (ratio of sorghum flakes:beans $=2: 1,2 \%$ RPO) which contained 8.59\% moisture, $2.38 \%$ ash, $15.26 \%$ protein, $21.38 \%$ fat, $3.67 \%$ crude fiber, $52.05 \%$ carbohydrates, $447 \mathrm{kcal}$ energy, $10.98 \%$ dietary fiber, $27,35 \mathrm{mg} / \mathrm{kg} \beta$-carotene, $23.00 \mathrm{mg} / \mathrm{kg}$ iron, $13.21 \mathrm{mg} / \mathrm{kg}$ zink, $304.40 \mathrm{mg} / \mathrm{kg}$ calcium, 48.69\% the limiting amino acid score, and $75.84 \%$ protein digestibility. F4 could be accepted by pregnant women with overall acceptability of $97 \%$. F4 potentially be used as one of the alternative supplementary food for pregnant women with chronic energy deficiency because of its acceptability, enable to fulfill supplementary food standard, and had higher protein and fiber content than existing supplementary food for pregnant women with chronic energy deficiency.
\end{abstract}

Keywords: beans, chronic energy deficiency, red palm oil, snack bar, sorghum

\section{INTRODUCTION}

Nutrition problem that still being focus in pregnant women is chronic energy deficiency (CED). Chronic energy deficiency is human condition which sustainable or yearly lack of nutrition or imbalance nutrition intake (energy and protein) showed by basal metabolic index (BMI) $<18,5 \mathrm{~kg} / \mathrm{m} 2$ which categorized as low and mid upper arm circumference (MUAC) $<23,5 \mathrm{~cm}$ (Indonesia Health Ministry, 2013). Based on Individual Food Consumption Survey (Survei Konsumsi Makanan Individu or SKMI) (2014), pregnant women has low energy adequacy intake ( $<70 \%$ energy adequacy level) and low protein adequacy intake $(<80 \%$ protein adequacy level) which categorized as very low (Indonesia Health Research and Development Center, 2014). Indonesia Health Ministry (2018a) showed based on energy adequacy, $53.9 \%$ pregnant women have energy deficiency ( $<70 \%$ energy adequacy level) and $13.1 \%$ categorized as mild deficiency $(70-90 \%$ energy adequacy level). Result also showed 51.9\% pregnant women have protein deficiency $(<80 \%$ protein adequacy level) and $18.8 \%$ categorized as mild deficiency (80-99\% protein adequacy level).

Based on Nutrition Status Evaluation result, percentage of pregnant women having energy deficiency risk in 2016, 2017, and 2018 in Indonesia is $16.2 \%, 14.8 \%$, and $17.3 \%$ (Indonesia Health Ministry, 2018b). That condition showed prevalence of chronic energy deficiency in pregnant women still categorized as poor nutritional condition (WHO, 1995). Nutrient deficiency especially in 1000 first days since conception until age of 2 years has short term and long term impact which harmful to mother and fetus (Akombi et al., 2017).

According to Poverty Eradication Acceleration National Team (2017), giving supplementary food to pregnant women can solve nutrition problem in pregnant women. Giving supplementary food to pregnant women which experienced nutrition problem has highest impact in second and third semester (Imdad et al., 2016). Supplementary 
food should be given in snack form because food supplementation in bigmeal form can decrease maternal nutrition status and generally are not on target (Nurina, 2016). Supplementary food in the form of snack bar can made as option because has balance nutrition, easy to bring, and can be consumed in between of meal time (Pallavi et al., 2015). Snack bar can be made from local food ingredients as source of energy and protein which it utilization not optimal yet like shorgum or nuts like red bean and black soy.

Shorgum is local food ingredient which its development can have potential to decrease dependency to import food ingredient, especially wheat and wheat flour, also has role to promote food diversification (Irawan dan Sutrisna, 2011). Shorgum has role as carbohydrate role, has higher protein content than corn, rice, and barley, also higher dietary fiber, iron, and calcium than wheat (Suarni, 2012). On the other hand, red bean has role as carbohydrate, protein, vitamin, mineral, which has complete essential amino acid content, also high antioxidant capacity (Messina, 2014; Fidrianny et al., 2014). Soy contain high protein with good amino acid profile and better protein digestability compare with other nuts. Black soybean has nutrition potential and production which not too different than yellow soybean, also has higher functional properties than yellow soybean (Malenčić et al., 2012; Xu dan Chang, 2007). Study by Utami et al. (2017) showed red bean, peanut, and soybean formula intervention can be used as drink for pregnant women with chronic energy deficiency which give impact to maternal nutrition status. Drink intervention for 30 days as much as $300 \mathrm{~mL}$ (1 glass) per day can increase body weight and mid upper arm circumference in second trimester pregnant women who diagnosed with chronic energy deficiency.

Sorghum are known having lower protein, fiber, and antioxidant content than nuts. To fix that condition, red bean and black soybean addition are made to complete food product nutrition value (Fauziyah et al., 2017). Beside that, according to Galili and Amir (2013), cereal have lisin limiting amino acid, while legum has metionin limiting amino acid. This condition showed combination between cereal and nuts can increase product amino acid quality.
Other main nutrition problem in pregnant women is vitamin A deficiency (Wijayanti, 2019). Red palm oil (RPO) addition as $\beta$-karoten source is important to increase sensory properties and nutrition value. $\beta$-carotene main role in body is as pro-vitamin A which will be processed by body so that it can transform into vitamin $\mathrm{A}$ and have role in mother and fetal vision and immune system maintenance, organ and bone development (Maia et al., 2019). Other than that, RPO has role in berperan producing colour characteristic, especially redness pigmen in many food industry products (Robiyansyah et al., 2017). Lietz et al. (2001) showed RPO addition as many as 12 gram in pregnant women in the early of third trimester until 3 months postpartum can increase pro-vitamin A activity while still consuming green vegetable. This condition marked with $\alpha$-carotene and $\beta$-carotene in breastmilk and blood plasma.

This study is expected can develop snacks with potential to optimalize pregnant women nutrition status and give positive impact to fetus. This study aim to develop and to analyze snack bar product made from sorghum with nuts (red bean and black soybean) with RPO addition as supplementary food alternative to pregnant woment with chronic energy deficiency.

\section{METHOD}

Study design is experimental in laboratory using complete random design with three repetition and factor in form of sorghum flakes and chopped nuts (redbean and black soybean) ratio with RPO addition so that obtained 6 formula. This study held between October 2018 to July 2019 in Food Processing and Experiment Laboratory, Organoleptic Laboratory, Chemistry and Food Analysis Laboratory, Community Nutrition Department, Faculty of Human Ecology, IPB University, Southeast Asian Food \& Agricultural Science \& Technology Center (SEAFAST) IPB University, Integrated Chemistry Laboratory IPB University, Big Agro Industry Center, and three integrated healthcare center in Sindang Barang Region Public Health Center, Bogor. This study had obtained agreement from Research Ethical Commision IPB University No:129/IT3.KEPMSMIPB/SK/2018. 


\section{Tools and Materials}

Main ingredients is sorghum flour that formed into flakes, redbean, and black soybean with RPO addition. Sorghum flour obtained from PT Agro Indah Permata 21 Bogor with Numbu variety which has brownish white or cream colour, black soybean obtained from Balai Penelitian Tanaman Aneka Kacang dan Umbi (BALITKABI) Malang with Detam 1 variety which has black skin colour and yellow bean, also RPO obtained from PT Nutri Palma Nabati Bogor.

\section{Snack Bar Formulation and Production Process}

Snack bar formulation are made based on technical guideline of Food Addition (Kementerian Kesehatan RI, 2017). Snack bar product development started by make sorghum flakes. Sorghum flakes made from sorghum flour mixed with granulated sugar, vanili powder, tapioka flour, maize flour, and egg yolk. The mixture then steamed, formed as pellet using grinder, cut, and rolled to optimalized physical aspect, nutrient content, and sensory properties especially texture (solidity, compactness, chewiness, stickiness) (Ribanar, 2014).

Next step is snack bar formulation which obtained based on modification result from energy snack bar recipe Andras et al. (2012) through trial and error. Product formulation were showed in table 1. Snack bar development started with mixing dry ingredients that is shorgum flakes, sesame seeds, chopped nuts, and sugar. Next, dehydrated cow milk (full cream), soy protein isolat, and white egg flour mixed with water until thick. After that, wet ingredients like melted chocolate, milk, soy protein isolate, and white egg flour mixture, peanut butter, egg, and RPO put into different bowl and mixed until homogen. Then, dry ingredients mixture and wet ingredients stirred until blended. Next step is the mixture were pour into baking sheet and bake in oven in $150 \mathrm{oC}$ for 30 minute.

\section{Snack Bar Organoleptic Test and Nutrient Analysis}

Sensory analysis through hedonic rating test using 30 semi trained panelist that is student of Community Nutrition Department, Faculty of Human Ecology IPB University. Hedonic rating test aimed to know panelist personal response based on likeliness level on every product atribute that is very dislike (1), dislike (2), less like (3), neutral (4), a little bit like (5), like (6), and very like (7) (Setyaningsih et al., 2010). Hedonic rating test atribute include colour, aroma, texture, taste, mouthfeel, aftertaste, and overall. After that, snack bar product performed protein analysis using

Table 1. Snack Bar Formulation per 100 gram

\begin{tabular}{lcccccc}
\hline \multicolumn{1}{c}{ Ingredients $(\mathbf{g})$} & F1 & F2 & F3 & F4 & F5 & F6 \\
\hline Sorghum Flakes & 28.67 & 21.51 & 14.34 & 28.37 & 21.28 & 14.18 \\
Redbean & 7.17 & 10.75 & 14.34 & 7.09 & 10.64 & 14.18 \\
Black Soybean & 7.17 & 10.75 & 14.34 & 7.09 & 10.64 & 14.18 \\
Melted Chocolate & 9.68 & 9.68 & 9.68 & 9.57 & 9.57 & 9.57 \\
Sesame seed & 2.15 & 2.15 & 2.15 & 2.13 & 2.13 & 2.13 \\
Egg & 2.15 & 2.15 & 2.15 & 2.13 & 2.13 & 2.13 \\
RPO & 1.08 & 1.08 & 1.08 & 2.13 & 2.13 & 2.13 \\
Milk Powder & 8.60 & 8.60 & 8.60 & 8.51 & 8.51 & 8.51 \\
Egg White Flour & 2.15 & 2.15 & 2.15 & 2.13 & 2.13 & 2.13 \\
Soy Protein Isolat & 5.38 & 5.38 & 5.38 & 5.32 & 5.32 & 5.32 \\
Peanut Butter & 19.35 & 19.35 & 19.35 & 19.15 & 19.15 & 19.15 \\
Sugar & 6.45 & 6.45 & 6.45 & 6.38 & 6.38 & 6.38 \\
Total & 100.00 & 100.00 & 100.00 & 100.00 & 100.00 & 100.00 \\
\hline
\end{tabular}

Note : formula for 4 pieces snack ar. F1: ratio between sorghum flake and nuts is $2: 1$ with RPO addition $1 \%$, F2: ratio between sorghum flake and nuts is $1: 1$ with RPO addition $1 \%, \mathrm{~F} 3$ : ratio between sorghum flake and nuts is $1: 2$ with RPO addition 1\%, F4: ratio between sorghum flake and nuts is $2: 1$ with RPO addition 2\%, F5: ratio between sorghum flake and nuts is 1:1 with RPO addition 2\%, serta F6: ratio between sorghum flake and nuts is $1: 2$ with RPO addition $2 \%$. 
Kjeldahl method in every formula. Determination of the chosen formula through sensory analysis and protein content from six formula (AOAC, 2005).

Next step, the chosen formula analyzed for chemical properties that is water analysis using oven method (AOAC, 2005), ash analysis using Gravimetri method (AOAC, 2005), fat analysis using Soxhlet method (AOAC, 2005), crude fiber analysis (AOAC, 2005), total carbohydrate analysis using by difference method (Andarwulan et al., 2011), energy analysis (Nielsen, 2010), total dietary fiber analysis using enzymatic method (Asp et al., 1984), $\beta$-carotene analysis (AOAC, 2000), mineral analysis (Fe, $\mathrm{Zn}, \mathrm{Ca})$ (AOAC, 2005), essential amino acid analysis using In House Method (Laboratorium Kimia Terpadu, 2002), and protein digestability analysis using in vitro method (Saunders et al., 1973). Last step is acceptability test for the chosen formula through hedonic rating test with 7 scales for attribute include colour, aroma, texture, taste, mouthfeel, aftertaste, and overall in 100 pregnant women as panelist.

\section{Data Analysis}

Sensory data and nutrient content were processed using Microsoft Excel 2010 and SPSS 16.0 for Windows. Sensory data analysis and protein content analyzed using one way ANOVA, then continued with Duncan's Multiple Range. Nutrient analysis result were showed in mean and deviation standard. Acceptance rate were analyzed by divided all panelist giving score 4 (neutral) until 7 (very like) with all panelist in total then multiplied with $100 \%$. After that, acceptance rate analysis result showed in graphic.

\section{RESULT AND DISSCUSION}

\section{Snack Bar Formulation}

Snack bar formulation as additional food determined based on three aspects that is additional food standard for pregnant women, balance energy protein, and product contribution as snacks. Based on Indonesia Health Ministry (2017), additional food for pregnant women have minimum $270 \mathrm{kcal}$ energy, 6 gram protein, and 12 gram fat. Study by Ota, et al. (2015) showed giving balance energy protein (not more than $25 \%$ energy than protein) can increase baby born weight and decrease baby mortality risk, low birth weight, premature baby, small fetus when pregnancy, and increase pregnant women body weight. Additional food hopefully can contributed as snack with amount $15-20 \%$ of Dietary Requirement Intake (Angka Kecukupan Gizi atau AKG) 2013 for second trimester pregnant women age 19-29 years old. Based on those consideration, appointed snack bar formula as showed below:

F1: Ratio between sorghum flake and nuts is $2: 1$ with RPO addition $1 \%$.

F2: Ratio between sorghum flake and nuts is $1: 1$ with RPO addition $1 \%$.

F3: Ratio between sorghum flake and nuts is $1: 2$ with RPO addition $1 \%$.

F4: Ratio between sorghum flake and nuts is $2: 1$ with RPO addition $2 \%$.

F5: Ratio between sorghum flake and nuts is 1:1 with RPO addition $2 \%$.

F6: Ratio between sorghum flake and nuts is $1: 2$ with RPO addition $2 \%$.

\section{Sensory Analysis and Nutrient Content to Determine the Chosen Formula}

Hedonic rating test result showed in table 2 . Table 2 showed highest mean based on panelist likeliness level are on formula F4. Based on oneway ANOVA result, each formula has significant difference on colour, aroma texture, mouthfeel, and overall properties $(\mathrm{p}<0.05)$. Result from Duncan test showed panelist likeliness level on five attribute of F3 and F6 are significant different, lower than other formula.

Based on table 2, the fewer usage of sorghum flakes and higher usage of nuts with RPO addition, then the lower panelist likeliness level on colour, aroma, texture, mouthfeel, and overall properties. Redbean and black soybean addition suspected has contribution to colour changes into brownish (dark) because maillard reaction during baking process. Maillard reaction is non enzymatic browning reaction because reaction between carbohydrate (reduction sugar) with amino chain (protein) on high temperature so that produce brownish colour on food (Winarno, 2008). Meanwhile based on Supriadji (2012), sorghum flour contributed to increase colour brightness because it has brightness level between 61.84-63.12 which close to 100 point (bright). Beside that, RPO contributed to give 
Table 2. Average of Sensory Analysis (Hedonic Rating Test) and Protein Content in Snack Bar

\begin{tabular}{lcccccccc}
\hline Formula & Colour & Aroma & Texture & Tase & Mouthfeel & Aftertaste & Overall & Protein (\%) \\
\hline F1 & $5.38 \pm 1.34^{\mathrm{a}}$ & $5.32 \pm 1.17^{\mathrm{ab}}$ & $4.85 \pm 1.47^{\mathrm{a}}$ & $5.00 \pm 1.34^{\mathrm{a}}$ & $4.93 \pm 1.22^{\mathrm{a}}$ & $4.77 \pm 1.20^{\mathrm{a}}$ & $5.15 \pm 1.26^{\mathrm{a}}$ & $15.01 \pm 0.09^{\mathrm{b}}$ \\
F2 & $5.08 \pm 1.14^{\mathrm{a}}$ & $5.43 \pm 0.89^{\mathrm{a}}$ & $4.70 \pm 1.32^{\mathrm{ab}}$ & $5.30 \pm 1.12^{\mathrm{a}}$ & $4.73 \pm 1.15^{\mathrm{ab}}$ & $4.75 \pm 1.08^{\mathrm{a}}$ & $5.20 \pm 0.90^{\mathrm{a}}$ & $15.54 \pm 0.48^{\mathrm{ab}}$ \\
F3 & $4.27 \pm 1.58^{\mathrm{b}}$ & $4.53 \pm 1.33^{\mathrm{c}}$ & $4.00 \pm 1.64^{\mathrm{c}}$ & $4.78 \pm 1.49^{\mathrm{a}}$ & $4.37 \pm 1.40^{\mathrm{b}}$ & $4.45 \pm 1.31^{\mathrm{a}}$ & $4.55 \pm 1.36^{\mathrm{b}}$ & $16.02 \pm 0.78^{\mathrm{a}}$ \\
F4 & $5.43 \pm 1.27^{\mathrm{a}}$ & $5.47 \pm 1.17^{\mathrm{a}}$ & $4.73 \pm 1.35^{\mathrm{ab}}$ & $5.32 \pm 1.37^{\mathrm{a}}$ & $4.95 \pm 1.08^{\mathrm{a}}$ & $4.88 \pm 1.22^{\mathrm{a}}$ & $5.33 \pm 1.08^{\mathrm{a}}$ & $15.26 \pm 0.25^{\mathrm{ab}}$ \\
F5 & $5.20 \pm 1.13^{\mathrm{a}}$ & $5.13 \pm 1.26^{\mathrm{ab}}$ & $4.33 \pm 1.40^{\mathrm{abc}}$ & $4.95 \pm 1.45^{\mathrm{a}}$ & $4.60 \pm 1.06^{\mathrm{ab}}$ & $4.55 \pm 1.17^{\mathrm{a}}$ & $4.88 \pm 1.15^{\mathrm{ab}}$ & $14.85 \pm 0.43^{\mathrm{b}}$ \\
F6 & $4.25 \pm 1.49^{\mathrm{b}}$ & $4.92 \pm 1.23^{\mathrm{bc}}$ & $4.17 \pm 1.57^{\mathrm{bc}}$ & $4.80 \pm 1.46^{\mathrm{a}}$ & $4.28 \pm 1.32^{\mathrm{b}}$ & $4.50 \pm 1.23^{\mathrm{a}}$ & $4.60 \pm 1.21^{\mathrm{b}}$ & $15.75 \pm 0.51^{\mathrm{ab}}$ \\
\hline
\end{tabular}

Note: Same letter in each same column showed no signfican differences $(p>0.05)$.

golden yellow colour which can increase product attraction (Marjan, 2016). Nuts like redbean and soybean contributed to produce unpleasant aroma because its lipoxigenase enzym component (Wiranata et al., 2017). In other hand, RPO can produce rancid aroma (Marjan, 2016).

Texture can affected by how many water content in ingredients. The higher water component in ingredients, the softer texture of its component (Santoso and Prakosa, 2010). One ingredient that high in water content is nuts. Redbean contain $66.94 \mathrm{gram} / 100$ gram of water, while boiled black soybean contain 58,8 gram/100 gram water (Chaudhary dan Sharma, 2013; National Institute of Agriculture Science, 2016). In other hand, RPO contributed in producecd cruncy texture but a little bit crumbly (Marjan, 2016). Based on Manonmani, et al (2014), nuts can decrease panelist acceptance on its mouthfeel because it forming residue in mouth.

Based on table 2 known that protein analysis result in each formula are 14.85-16.02\% (ww). One-way ANOVA result showed that formula differences can give significant impact to protein level $(\mathrm{p}<0.05)$. Duncan test showed that protein level in F3 has significant difference, higher than F1 and F5. But protein level in F3 has no difference with F2, F4, and F6. Ingredients that suspected contribute in protein content increment is nuts which redbean has 8.67 gram per 100 gram protein and black soybean has 39.09 gram per 100 gram protein (Chaudhary and Sharma, 2013; Nurrahman, 2015). Meanwhile, high protein supporting ingredients addition suspected can support increasing of protein content in product like full cream milk powder, soy protein isolat, white egg flour, and peanut butter. Protein has

Tabel 3. The Chosen Snack Bar Product Formula Nutrient Content (F4)

\begin{tabular}{lccc}
\hline \multicolumn{1}{c}{ Nutrient Content } & Mean \pm SD & $\begin{array}{c}\text { Additional Food Standard for } \\
\text { Pregnant Women with Chronic } \\
\text { Energy Deficiency* }\end{array}$ & $\begin{array}{c}\text { Additional Food Standard } \\
\text { for Pregnant Women * }\end{array}$ \\
\hline Water (\%) & $8.93 \pm 0.17$ & 2.39 & - \\
Ash (\%) & $2.38 \pm 0.04$ & - & Min. 6.00 \\
Protein (\%) & $15.26 \pm 0.25$ & 10.14 & Min. 12.00 \\
Fat (\%) & $21.38 \pm 0.22$ & 20.89 & - \\
Total Carbohydrate (\%) & $52.05 \pm 0.17$ & - & Min. 270 \\
Energy (kcal) & $447 \pm 2.54$ & 487 & - \\
Rough Fiber (\%) & $3.67 \pm 0.51$ & - & - \\
Total Dietary Fiber (\%) & $14.44 \pm 0.27$ & 6.19 & - \\
$\quad$ Soluble Dietary Fiber (\%) & $2.06 \pm 0.12$ & - & - \\
Insoluble Dietary Fiber (\%) & $12.37 \pm 0.39$ & - & - \\
$\beta$-carotene (mg/kg) & $27.35 \pm 0.49$ & 11.42 & - \\
Iron (mg/kg) & $23.00 \pm 1.74$ & 10.41 & - \\
Zinc (mg/kg) & $13.20 \pm 0.80$ & 277.53 & - \\
Calcium (mg/kg) & $330.61 \pm 37.12$ & - & - \\
\hline
\end{tabular}

Note: *Indonesia Health Ministry 2017; Min = minimum level; - = data were not found. 
role in increasing protein syntesis to maintain maternal tissue and babies growth, especially in third trisemester (Kramer and Kakuma, 2003). Energy from protein in the early of pregnancy can increase birthweight and plasenta (Ghosh, 2016). Balance protein energy intervention (not more than $25 \%$ energy from protein) can increase babies birthweight, decrease birth mortality, and increase baby size (Ota et al., 2015).

Hedonic rating test result showed all attribute in F4 has higher point than other formula. Protein level analysis also showed F4 has no significant differences than other formula. For that reason, F4 determined as the chosen formula.

\section{Chemical Properties of the Chosen Formula}

Nutrient content of the chosen formula are showed in table 3 . Nutrient analysis result showed the chosen formula (F4) has fulfill minimum requirement of protein (6 gram), fat (12 gram), and energy ( $270 \mathrm{kcal})$ of additional food for pregnant women. F4 contain $8,93 \%$ water (ww). Additional food product to pregnant women with chronic energy deficiency that has already produced have $2.39 \%$ water content. Study result by Ribanar (2014) showed snack bar made from sorghum flakes has $5,43 \%$ water content. Water content of this product were higher that previous product which caused by the usage of chopped boiled nuts. Boiled redbean and black soybean contain respectively 66.94 gram and 58.8 gram per 100 gram water so that it contributed to increase water content of product (Chaudhary and Sharma, 2013; National Institute of Agriculture Science, 2016).

Ash analysis result showed F4 contain 2,38\% ash (ww). Ash content showed mineral amount in food. The higher ash content in food, the higher mineral content in those food (Andarwulan et al., 2011). Based on Indonesia Health Ministry (2017), additional food product for pregnant woment with chronic energy deficiency needs to contain 10,14 gram protein per 100 gram. F4 has higher protein content rather than additional food for pregnant women with chronic energy deficiency that has produced previously. Beside that, F4 can be claimed as protein sources because fulfill at least 20\% Nutrition Label Guideline (Acuan Label Gizi or ALG) per 100 gram in solid form (BPOM RI, 2016).
Result of fat analysis showed F4 contain $21,38 \%$ fat (ww). Based on Berdasarkan Kementerian Kesehatan RI (2017), Based on Indonesia Health Ministry (2017), additional food product for pregnant woment with chronic energy deficiency that previosly produced contain 20,89 gram per 100 gram. This condition showed F4 not too far than previous additional food product. Fat source ingredients in product include RPO, sesame seed, peanut butter, chocolate, and full cream milk.

Calculation result showed total carbohydrate in F4 is $52,05 \%$. Carbohydrate sources in product is sorghum, chocolate, full cream milk, and nuts. Content calculation result showed F4 formula has 447 kkal energy. Based on study by Ribanar, (2014), snack bar made from sorghum flakes contain 450 kkal energy. This condition showed energy content in F4 formula is not too different than previous snack bar product. F4 formula with $15,26 \%$ protein can contribute to $13,7 \%$ energy source. Liberato, et al. (2013) stated giving balance energy-protein in pregnancy as much as $12,3 \%$ energy from protein can increase fetal growth.

Analysis result of dietary fiber content in F4 formula showed product contain 14,44\% (ww) total dietary fiber with $2,06 \%$ (ww) soluble dietary fiber and $12,37 \%$ (ww) insoluble dietary fiber. Based on Indonesia Health Ministry (2017) additional food product for pregnant women with chronic energy deficiency which already publish has 6,19 gram per 100 gram dietary fiber. This condition showed dietary fiber in F4 has higher dietary fiber content that previous product. F4 can be claimed as high dietary fiber product because has more than 6 gram per 100 gram dietary fiber in solid form (Indonesia Food Drug Administration Center, 2016). This condition caused by used ingredients dominated by dietary fiber sources like sorghum flakes $(28,37 \%$ in mixture) with fiber content in sorghum as much as 6,60-6,21 gram per 100 gram, nuts $(14,18 \%$ in mixture) with dietary fiber content as much as 6,05 gram per 100 gram in redbean, and dietary fiber content in black soybean as much as 10,5 gram per 100 gram (Chaudhary and Sharma, 2013; National Institute of Agriculture Science, 2016).

Analysis result showed F4 formula contain $27,35 \mathrm{mg} / \mathrm{kg} \beta$-carotene. This condition caused by 
$2 \%$ red palm oil (RPO) addition which contain carotenoid ( $\alpha$ - dan $\beta$-carotene) in high amount. Based on Zeb and Malook (2009), RPO were natural food source rich in $\beta$-carotene that is 250 $350 \mathrm{ppm}(\mathrm{mg} / \mathrm{kg})$. F4 formula can be claimed as high in $\beta$-carotene because contain $\beta$-karoten more than $1,469 \mathrm{mg}$ per $100 \mathrm{~g}(1469 \mu \mathrm{g} / 100 \mathrm{~g} \approx 14,69$ $\mu \mathrm{g} / \mathrm{g} \approx 30 \%$ ALG $\beta$-carotene, Vitamin A conversion result) (Indonesia Food and Drugs Administration Center, 2016).

Mineral analysis result showed $\mathrm{F} 4$ formula contain $23,00 \mathrm{mg} / \mathrm{kg}$ iron, $13,21 \mathrm{mg} / \mathrm{kg}$ zinc, and $330,61 \mathrm{mg} / \mathrm{kg}$ calcium. Mineral content in F4 fulfill 7\% iron RDI, 8\% zinc RDI, and 3\% calcium RDI which lower than previous additional food product This condition caused by previous additional food used vitamin and mineral premix meanwhile F4 formula did not used vitamin and mineral premix. Other than that, anti nutrition in sorghum and nuts like tanin, phytat, and protease inhibitor causing bond formation between anti nutrition and important mineral so that it can form complex compound which decrease mineral availability (Haliza, et al., 2007). Based on RDI 2013 for second pregnant women with age 1929 years, 100 gram F4 as snacks can fulfill daily energy requirement as much as $18 \%$, protein $20 \%$, fat $25 \%$, carbohydrate $15 \%$, dietary fiber $31 \%$, and $\beta$-carotene $57 \%$. Meanwhile, mineral like iron,

Table 4. Profile and limiting essential amino acid score in F4

\begin{tabular}{lccc}
\hline $\begin{array}{c}\text { Essential } \\
\text { amino acid }\end{array}$ & $\begin{array}{c}\text { Essential } \\
\text { amino acid } \\
\text { mg/g protein }\end{array}$ & $\begin{array}{c}\text { Essential } \\
\text { amino } \\
\text { acid } \\
\text { reference* }\end{array}$ & $\begin{array}{c}\text { \% essential } \\
\text { amino acid } \\
\text { score }\end{array}$ \\
\hline Histidine & $28.51 \pm 0.46$ & - & - \\
Isoleuscine & $54.72 \pm 1.39$ & 40 & 136.80 \\
Leucine & $99.61 \pm 5.56$ & 70 & 142.30 \\
Valin & $64.88 \pm 3.71$ & 50 & 129.76 \\
Lysine & $54.39 \pm 5.56$ & 55 & 98.89 \\
Threonine & $38.66 \pm 0.93$ & 40 & 96.65 \\
Phenylalanine & $65.53 \pm 1.85$ & - & - \\
Methionine & & & \\
+ cysteine & $17.04 \pm 0.00$ & 35 & 48.69 \\
(sulphuric & & & \\
amino acid) & & 10 & 98.30 \\
Tryptophan & $9.83 \pm 0.00$ & &
\end{tabular}

Note: *FAO 1973 zinc, calcium only can fulfill respectively $7 \%, 9 \%$, and $3 \%$ daily requirement.

Protein quality in F4 formula can be measured using limiting essential amino acid and protein digestability measurement. Limiting essential amino acid are amino acid that cannot produce in body so that it must be obtained from balance nutrition. Limiting essential amino acid consisted by histidine, isoleucine, leucine, valin, lysine, threonine, phenylalanine, methionine + cysteine, and tryptophan (Górska-Warsewicz et al., 2018). Profile and limiting essential amino acid score in F4 showed in table 4.

Based on calculation by dividing essential amino acid score in product with amino acid requirement for adult based on FAO (1973) then multiply with 100 , lowest essential amino acid score showed by methionine and cysteine as much as $48,69 \%$ (FAO, 1973). This condition showed limiting essential amino acid in product is methionine and cysteine which only 48,69\% from total amino acid in product which can be used by body to protein synthesis. Based on Patil, et al. (2016), nuts contain methionine, cysteine, and tryptophan in low amount. For that reason, product needs ingredients which can completing essential amino acid like animal protein and cereal (GórskaWarsewicz, et al., 2018; Galili and Amir, 2013).

Protein digestability analysis result in F4 formula showed digestable protein in snack bar product is $75,84 \%$ which categorized as not high. Based on Sediaoetama (1991), high protein digestability equal to or higher than $80 \%$. This condition caused by internal like animal protein usage which lower than plant based protein. Animal protein are high quality protein because contain complete essential amino acid and its form near to amino acid which needed by body to maintain growth nad metabolic process in human body. Meanwhile plant based protein from nuts contain suboptimal essential amino acid (Joye, 2019). Other internal factor which can affect protein digestability is folded and agregation protein which can blocking entrance to peptide chain so that it can slowing hydrolisis process Beside that, cross bond in and between single protein can decrease protein digestability (Joye, 2019).

External factor also contributed to affect protein digestabilty. Based on Joye (2019), 
heating process can affect protein digestability by causing protein denaturation and continued with aggregation. Other external factor can affect protein digestability is anti nutrition content in sorghum, redbean, and black soybean like tannin, phytate, and dan protease inhibitor which can compete with peptidase and nonactivate peptidase (Duodu et al., 2003; Chaudhary and Sharma, 2013; Yang et al., 2014; Joye, 2019). F4 can be claimed as high fiber. Based on Joye (2019), fiber can increase gastrointestinal tract viscosity so that it is suspected can slowing hydrolitic enzyme diffusion in producing amino acid.

Protein digestability score increment can be done by fermentating black soybean. Based on Çabuk et al. (2018), fermentation can decrease anti nutrition content that can inhibit trypsin and kimotrypsin inhibitor enzyme also decrease anti nutrition which can stimulating cross bond (phenolic and tannin compound). Other than that, fermentation can produce protease from microe that help to degrade protein into amino acid and help release protein from matrix.

\section{Chosen Snack Bar Product Acceptability in Pregnant Women}

Product acceptability can be measured using hedonic rating test. Like response obtained from person that representing general opinion or community population (Setyaningsih et al., 2010). For that reason, acceptability analysis to F4 held in 100 pregnant women. Result showed scale 4 (neutral) until 7 (very like) in product and showed product can be accepted by panelist. Based on Setyaningsih, et al. (2010), if consumer percetage which stated not like (refuse) product $<50 \%$, than that product can be accepted by consumer. Study result showed chosen snack bar formula can be accepted by pregnant women as panelist because $>50 \%$ panelist choose scale $4-7$ in each hedonic attribute. Colour properties has $92 \%$ acceptance percentage, aroma properties $93 \%$, texture properties $86 \%$, taste and mouthfeel properties $93 \%$, aftertaste properties $89 \%$, and overall properties $97 \%$. Panelist acceptance percentage (pregnant women) in $\mathrm{F} 4$ formula showed in picture 1.

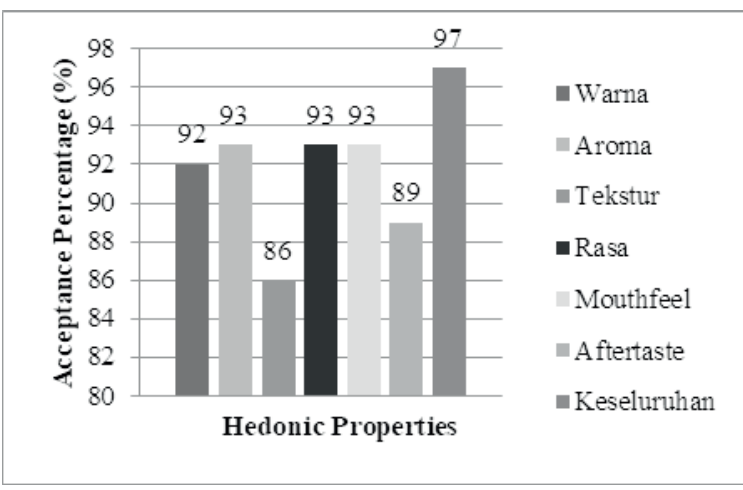

Gambar 1. Panelist Acceptance Percentage (Pregnant Women) in Formula F4

\section{CONCLUSION}

The choosen Snack bar (F4) has potential as additional food alternative for pregnant women with chronic energy deficiency. F4 can be accepted in sensory properties, fulfill minimum nutrient standard for additional food for pregnant women with balance energy protein, contain higher protein and fiber that other commercial additional food for pregnant women with chronic energy protein, can be claimed as protein source, high fiber, high $\beta$-carotene, and can contributed to fulfill nutrient requirement as snacks for pregnant women. But, F4 still not fulfill daily mineral requirement especially $\mathrm{Fe}, \mathrm{Zn}$, and $\mathrm{Ca}$ as snacks and $\mathrm{F} 4$ has low protein digestability. For suggestion, fortificant premix addition into the product are necessary to increase mineral content. Beside that, nutrient addition especially protein quality protein are needed by adding animal protein sources which has optimal essential amino acids and perform some process to increase protein digestability like black soybean fermentation

\section{ACKNOWLEDGEMENT}

Researcher would like to say thank you to Indonesia Health Ministry which has funded this study, Sindang Barang Kota Bogor Public Health Centre, healthcare practitioner in Sindang Barang Region, and pregnant women in Sindang Barang. Researcher also want to say thank you to supervisor commission who gave input and suggestion, and all academics in Nutrition Undergraduate and Graduate Program, IPB University. 


\section{REFERENCE}

Akombi, B.J., Agho, K.E., Hall, J.J., Wali, N., Renzaho, A.M.N., \& Merom, D. (2017). Stunting, wasting and underweight in Sub-Saharan Africa: A systematic review. International Journal of Environmental Research and Public Health, 14(8), 1-18. doi:10.3390/ijerph14080863

Andarwulan, N., Kusnandar, F., \& Herawati, D. (2011). Analisis Pangan. Jakarta: Dian Rakyat.

Andras, D., Gautney, J., Patterson, J., \& Selden, D. (2012). Alteration of two ingredients in controlled granola energy bar sample yields better sensory appeal of color but not texture or flavor in a Bastyr community sample. Experimental Food Science Journal, 37, 773-782.

Asp, N., Prosky, L., Furda, L., De Vries, J., Schweizer, J., \& Harland, B. (1984). Determination of total dietary fiber in foods and food products and total diets: Interlaboratory study. Journal of $A O A C$, 68(4), 1044-1053.

Association of Official Analytical Chemist (AOAC). (2000). Official Methods of Analysis of AOAC International 17th ed. Arlington, VA: AOAC International.

Association of Official Analytical Chemist (AOAC). (2005). Official Methods of Analysis of AOAC International 18th ed. Washington, DC: AOAC International.

Chaudhary, R., \& Sharma, S. (2013). Conventional nutrients and antioxidants in red kidney beans (Phaseolus vulgaris L.): an explorative and product development endeavour. Food Science and Technology, 14(2), 275-285.

Duodu, K.G., Taylor, J.R.N., Belton, P.S., \& Hamaker, B.R. (2003). Factors affecting sorghum protein digestibility. Journal of Cereal Science, 38(2), 117-131. doi:10.1016/S07335210(03)00016-X

Fauziyah, A., Marliyati, S.A., \& Kustiyah, L. (2017). Substitusi tepung kacang merah meningkatkan kandungan gizi, serat pangan dan kapasitas antioksidan beras analog sorgum. Jurnal Gizi Dan Pangan, 12(2), 147-152. doi:10.25182/ jgp.2017.12.2.147-152

Fidrianny, I., Puspitasari, N., \& Singgih, M.W. (2014). Antioxidant activities, total flavonoid, phenolic, carotenoid of various shells extracts from four species of legumes. Asian Journal of Pharmaceutical and Clinical Research, 7(4), 42-46.
Food and Agriculture Organization (FAO). (1973). Energy and protein requirements: WHO Technical Report Series No. 52.

Galili, G., \& Amir, R. (2013). Fortifying plants with the essential amino acids lysine and methionine to improve nutritional quality. Plant Biotechnology Journal, 11(2), 211-222. doi:10.1111/pbi.12025

Ghosh, S. (2016). Protein quality in the first thousand days of life. Food and Nutrition Bulletin, 37(Supplement 1), S14-S21. doi:10.1177/0379572116629259

Górska-Warsewicz, H., Laskowski, W., Kulykovets, O., Kudlińska-Chylak, A., Czeczotko, M., \& Rejman, K. (2018). Food products as sources of protein and amino acids - the case of Poland. Nutrients, 10(12). doi:10.3390/nu10121977

Haliza, W., Purwani, E.Y., \& Ridwan, T. (2007). Pemanfaatan kacang-kacangan lokal sebagai substitusi bahan baku tempe dan tahu. Buletin Teknologi Pascapanen Pertanian, 3, 1-8.

Imdad, A., Lassi, Z., Salaam, R., \& Bhutta, Z.A. (2016). Prenatal nutrition and nutrition in pregnancy: effects on long-term growth and development. In Early Nutrition and LongTerm Health: Mechanisms, Consequences, and Opportunities. doi:10.1016/B978-0-08-1001684.00001-X

Indonesia Food and Drugs Administration Center (2016). Peraturan Kepala Badan Pengawas Obat dan Makanan Republik Indonesia Nomor 9 Tahun 2016 tentang Acuan Label Gizi. In Badan Pengawasan Obat dan Makanan Republik Indonesia Jakarta: BPOM RI.

Indonesia Health Ministry. (2013). Riset Kesehatan Dasar (RISKESDAS) 2013. In Laporan Nasional 2013. Retrieved from : http://www.depkes.go.id/ resources/download/general/Hasil Riskesdas 2013.pdf

Indonesia Health Ministry. (2017). Petunjuk Teknis Pemberian Makanan Tambahan (Balita-Ibu Hamil-Anak Sekolah). Retrieved from : https:// cegahstunting.id/wp-content/uploads/2018/01/ Juknis-PMT-2017-2.pdf

Indonesia Health Ministry. (2018b). Buku Saku Nasional Pemantauan Status Gizi 2017. Retrieved from : http://www.kesmas.kemkes. go.id/assets/upload/dir_519d41d8cd98f00/files/ Buku-Saku-Nasional-PSG-2017_975.pdf

Irawan, B., \& Sutrisna, N. (2011). Prospek pengembangan sorgum di Jawa Barat mendukung diversifikasi pangan. 29(2), 99- 
113. Retrieved from : https://media.neliti. com/media/publications/55690-ID-prospekpengembangan-sorgum-di-jawa-bara.pdf

Indonesia Health Research and Development Center (2014). Studi Diet Total: Survei Konsumsi Makanan Individu Indonesia 2014. Retrieved from : https://docplayer.info/59466407-Bukustudi-diet-total-survei-konsumsi-makananindividu-indonesia-2014.html

Joye, I. (2019). Protein digestibility of cereal products. Foods, 8(6), 199. doi:10.3390/ foods 8060199

Kramer, M.S., \& Kakuma, R. (2003). Energy and protein intake in pregnancy. Cochrane Database of Systematic Reviews, (4). doi:10.1002/14651858.cd000032

Laboratorium Kimia Terpadu. (2002). In House Method Analisis Asam Amino. Bogor: Institut Pertanian Bogor.

Liberato, S.C., Singh, G., \& Mulholland, K. (2013). Effects of protein energy supplementation during pregnancy on fetal growth: A review of the literature focusing on contextual factors. Food and Nutrition Research, 57(1). doi:10.3402/fnr. v57i0.20499

Lietz, G., Henry, C.J.K., Mulokozi, G., Mugyabuso, J.K.L., Ballart, A., Ndossi, G.D., ... Tomkins, A. (2001). Comparison of the effects of supplemental red palm oil and sunflower oil on maternal vitamin A status. American Journal of Clinical Nutrition, 74(4), 501-509. doi:10.1093/ ajen/74.4.501

Maia, S.B., Souza, A.S.R., Caminha, M.D.F.C., da Silva, S.L., Cruz, R. de S.B.L.C., Dos Santos, C.C., \& Filho, M.B. (2019). Vitamin a and pregnancy: A narrative review. Nutrients, 11(681), 1-18. doi:10.3390/nu11030681

Malenčić, D., Cvejić, J., \& Miladinović, J. (2012). Polyphenol content and antioxidant properties of colored soybean seeds from central Europe. Journal of Medicinal Food, 15(1), 89-95. doi:10.1089/jmf.2010.0329

Manonmani, D., Bhol, S., \& Bosco, S.J.D. (2014). Effect of red kidney bean (Phaseolus vulgaris L.) flour on bread quality. OALib, 01(01), 1-6. doi:10.4236/oalib.1100366

Marjan, A. (2016). Pemanfaatan Red Palm Oil sebagai Sumber Antioksidan pada Produk Pangan Fungsional yang Berpotensi untuk Mencegah Atherosklerosis (Master thesis). Institut Pertanian Bogor, Bogor.
Messina, V. (2014). Nutritional and health benefits of dried beans. American Journal of Clinical Nutrition, 100(SUPPL. 1), 3S-6S. doi:10.3945/ ajcn.113.071472

National Institute of Agriculture Science. (2016). Korean Food Composition Table 9th Revision. Iseol: National Institute of Agriculture Science.

Nielsen, S.S. (2010). Food Analysis. chapter 14:Fat Characterrization pp 251-252. In Nature. doi:10.1038/1841347a0

Nurina, R. (2016). Program pemberian makanan tambahan untuk peningkatan status gizi ibu hamil dan balita di Kecamatan Cilamaya Kulon dan Cilamaya Wetan, Karawang. Jurnal CARE Jurnal Resolusi Konflik, CSR, Dan Pemberdayaan, 1(1), 44-49.

Nurrahman. (2015). Evaluasi komposisi zat gizi dan senyawa antioksidan kedelai hitam dan kedelai kuning. Jurnal Aplikasi Teknologi Pangan, 4(3), 89-93.

Ota, E., Hori, H., Mori, R., Tobe-Gai, R., \& Farrar, D. (2015). Early intervention for psychosis [Systematic Review]. Cochrane Database of Systematic Reviews, (4).

Pallavi, B.V., Chetana, R., Ravi, R., \& Reddy, S.Y. (2015). Moisture sorption curves of fruit and nut cereal bar prepared with sugar and sugar substitutes. Journal of Food Science and Technology, 52(3), 1663-1669. doi:10.1007/ s13197-013-1101-0

Patil, S., Brennan, M., Mason, S., \& Brennan, C. (2016). The effects of fortification of legumes and extrusion on the protein digestibility of wheat based snack. Foods, 5(26), 1-8. doi: 10.3390 /foods 5020026

Ribanar, A.A. (2014). Designing Sorghum (Sorghum bicolor (L.) Moench) Flakes Based Snack Bar for Nutritional and Health Benefits of Children (Master Thesis). University of Agricultural Sciences, Dharwad.

Robiyansyah, Zuidar, A., \& Hidayati, S. (2017). Pemanfaatan minyak sawit merah dalam pembuatan biskuit kacang kaya beta karoten. Jurnal Teknologi Industri \& Hasil Pertanian, 22(1), 11-20.

Santoso, A., \& Prakosa, C. (2010). Karakteristik tape buah sukun hasil fermentasi penggunaan konsentrasi ragi yang berbeda. Magistra, 22(73), 48-55.

Saunders, R.M., Connor, M.A., Booth, A.N., Bickoff, E.M., \& Kohler, G.O. (1973). Measurement of 
digestibility of alfalfa protein concentrates by in vivo and in vitro methods. The Journal of Nutrition, 103(4), 530-535. doi:10.1093/ $\mathrm{jn} / 103.4 .530$

Sediaoetama, A. (1991). Ilmu Gizi untuk Mahasiswa dan Profesi Jilid 1. Jakarta: Dian Rakyat.

Setyaningsih, D., Apriyanto, A., \& Sari, M. (2010). Analisis Sensori untuk Industri Pangan dan Agro. Bogor: IPB Press.

Suarni. (2012). Soghum potential as a fungtional food. Iptek Tanaman Pangan, 7(1), 58-66.

Supriadji. (2012). Karakterisasi Sifat Fisik dan Kimia Tepung Sorgum (Sorgum bicolor L) Rendah Tanin (Master Thesis). Institut Pertanian Bogor, Bogor.

Poverty Eradication Acceleration National Team. (2017). 100 Kabupaten/Kota Prioritas untuk Penanganan Anak Kerdil (Stunting) (Vol. 2). Retrieved from : http://www.tnp2k.go.id/ images/uploads/downloads/Binder_Volume1. pdf

Utami, N.W., Majid, T.H., \& Herawati, D.M.D. (2017). Pemberian minuman formula kacang merah, kacang tanah, dan kacang kedelai terhadap status gizi ibu hamil kurang energi kronis (KEK). Jurnal Gizi Klinik Indonesia, 14(1), 1. doi:10.22146/ijen.22424
Wijayanti, I.T. (2019). Pola makan ibu hamil yang mempengaruhi kejadian KEK di Puskesmas Gabus I Kabupaten Pati. Jurnal SMART Kebidanan, 6(1), 5. doi:10.34310/sjkb. v6i1.226

Winarno, F. (2008). Kimia Pangan dan Gizi. Jakarta: M-BRIO PRESS.

World Health Organisation (WHO). (1995). Physical Status: The Use and Interpretation of Anthropometry. Retrieved from : https://apps. who.int/iris/bitstream/handle/10665/37003/ WHO_TRS_854.pdf;jsessionid=B5782AC56D 06E77AA3DE2C442A4A2322? sequence $=1$.

Xu, B.J., \& Chang, S.K.C. (2007). A comparative study on phenolic profiles and antioxidant activities of legumes as affected by extraction solvents. Journal of Food Science, 72(2), S159S166. doi:10.1111/j.1750-3841.2006.00260.x

Yang, H.W., Hsu, C.K., \& Yang, Y.F. (2014). Effect of thermal treatments on anti-nutritional factors and antioxidant capabilities in yellow soybeans and green-cotyledon small black soybeans. Journal of the Science of Food and Agriculture, 94(9), 1794-1801. doi:10.1002/jsfa.6494

Zeb, A., \& Malook, I. (2009). Biochemical characterization of sea buckthorn (Hippophae rhamnoides L. spp. turkestanica) seed. African Journal of Biotechnology, 8(8), 1625-1629. 